\title{
COLLABORATIVE STRATEGIC READING (CSR) IN IMPROVING THE ENGLISH DEPARTMENT STUDENTS' READING COMPREHENSION ACHIEVEMENT
}

\author{
Ahmad Ridho Rojabi \\ IAIN Jember \\ ahmadridhorojabi@gmail.com
}

\begin{abstract}
Reading as a receptive skill is very important skill for all students of English because it is a skill that everyone needs in studying or conveying the language. However, it is very difficult for the students to catch the message from the reading text as they have limited words and reading strategies. The aim of this research is to prove whether the implementation of Collaborative Strategic Reading (CSR) is effective to improve students' reading comprehension. To achieve the purpose, the classroom action research design was employed by following four stages: planning, implementing, observing, and reflecting. This research was implemented in two cycles, in which both the first cycle and the second cycle were carried out in two meetings. CSR is implemented to teach students reading comprehension in cooperative learning groups. CSR consists of four strategies that are implemented in pre-reading, whilst reading, and post-reading. CSR strategies consist of: (1) preview the text, (2) click and clunk, (3) get the gist, and (4) wrap up. The result of the research revealed that Collaborative Strategic Reading (CSR) improved the students' reading comprehension achievement on the fourth semester of English departmentat IAIN Jember.
\end{abstract}

Keywords: collaborative strategic reading, reading comprehension achievement, classroom action research

\section{INTRODUCTION}

Learning English is important for people all over the world. As a global language, it is obvious that English plays an important role in the international interaction. International interactions include economic relationships among countries, international business relationship, global trading, and others. In this kind of international interactions, English mainly acts as a global lingua franca. Lingua franca is a language that is used to communicate among different people from different countries (Sneddon, 2003). Speaking English will increase the students' chances of getting a good job and finding work abroad. At university, English teaching aims at developing students' ability in using English both in oral and written forms. In other words, they are expected to master four language skills namely; listening, speaking, reading and writing.

Based on the statement above, reading and listening are considered as receptive skills, while speaking and writing are considered as productive skills. Reading comprehension is an important skill needed for all areas of school. Subjects, others than reading or literature, where comprehension skills are 
significantly important include science, social studies, and Math (Best, Rowe, Ozura, and McNamara, 2005). There are a lot of teaching activities can be carried out by using reading passages. English teacher can teach students structure, vocabulary, pronunciation, writing, speaking, and listening, besides reading itself.

Reading is a receptive language process, where meaning decodes from the author's thinking. It is a psycholinguistic process in that it starts with a linguistic surface representation encoded by a writer and end with meaning, which the reader constructs. Thus, there is an essential interaction between language and thought while someone is reading a text. The writer encodes thought as language and the reader decodes language into thought (Carrell, 1983:13). In short, the students are expected to do more than just read the text. They must recognize the printed materials and gain the meaning. They at last can identify the message of the author expressed in the written text.

According to Boss and Vaughn (1991: 92-95), reading is meaning based, entails the active construction of meaning, and requires the reader to be strategic and to interact with the text. Then, Boss and Vaughn state the following five concepts of reading. (1) Reading is an active search for meaning. It means that since reading entails-constructing meaning, it requires the reasoning and thinking process, sometimes called comprehension. (2) Reading is the process of constructing meaning from the text. It means that when reading the text, the writer does not simply convey ideas to the reader but stimulates the reader to construct meaning. (3) Reading is strategic process. It means that reading requires the reader to use a variety of thinking strategies to derive meaning from the text. (4) Reading is the interactive process. It means that when the reader reads the text, he or she also interacts with ideas presented by the writer. The reader uses his or her knowledge about oral and written language to guide the reading process. (5) Reading is a language learning activity socially mediated. When children and the teacher talk about what they are reading, they share what they already know related to the topic and integrate their knowledge that s relevant to them.

Hennings (1997) states that reading is a basic skill of communication, it is used most effectively when it supplements and enriches the material gained in other ways. In line with this, Wood (1996) also states that reading will become a valuable source of information when it is learned to get meaning from different types of material and to read for a variety of purposes. So, it can be concluded that reading is the important thing to get some information from different types of material and for different purposes.

To be able to get information needed, students should read the available resources. For example, if students need to find information about job vacancy, they can read newspapers, or if they want to have information about music or popular songs, they will read music magazine, or they can also read novels if they need to read for pleasure. In line with the above explanation, Grellet (1981) confirms that students read for many different reasons, some read for information and some read for pleasure.

Reading comprehension in this study deals with students' ability to understand reading text. According to Hennings (1997: 245), comprehension means interacting and constructing meaning to the text, In line with this, Fairbairn and Winch (1996) also confirms that we read in order to gain meaning from the text. Based on the explanations above, it can be concluded that reading 
comprehension is the process of interaction between the written information and the reader by understanding the written language associated with the readers' language skills and their acquired knowledge.

Thus the basic comprehension units in reading are words, sentence, and paragraph (Hennings, 1997: 269). In other words, students should comprehend the word, sentence, and paragraph to gain meaning from the text. In reality, however, many students do not know how to read the printed materials comprehensively. They may be able to read faster but they do not understand the passage nor can they get the message from the material very well.

To overcome the students' problem in general with reading comprehension, the teachers' role becomes important in the teaching and learning process especially in choosing the best teaching method and materials. For example, the teacher should apply an appropriate strategy in teaching reading in the class that is providing activities to help students understand the information from the textbook. The strategy should help students raise their background knowledge to make prediction about the content of the text and also help students get more information, details and examples after reading activities.

Based on the identified problems that the students of the reading class being studied, it is very important to find the solution to solve the student's problem in order to improve their comprehension in reading the text. For solving the problem, the researcher propose the use of Collaborative Strategic Reading (CSR), especially to improve the students' reading comprehension.

Klingner and Vaughn (2000: 75) stated that CSR is a classroom strategy developed to take advantage of the potentials of collaboration for language development in the classrooms that students of various reading and achievement levels work in small cooperative group to assist one another in applying the four reading strategies, that are Preview, Click\& Clunk, Get the Gist and Wrap Up to facilitate their comprehension of reading content-area text.

By doing so,the students are asked to applied the four reading strategies, namely preview, click and clunk, get the gist and wrap up strategy collaboratively. By the use of the four reading strategies in Collaborative Strategic Reading (CSR) can solve the identified problems related to students' reading comprehension.

CSR was developed by Klingner and Vaughn in 1998. CSR is a reading comprehension technique that combines two instructional elements: (1) modified reciprocal teaching (Palincsar and Brown, 1984) and (2) cooperative learning or students pairing (Johnson and Johnson, 1987). In reciprocal teaching, teacher and students take turns leading a dialogue concerning key feature of the text through summarizing, questioning, clarifying and predicting, and in cooperative learning, the students brainstorming, predict, clarify words and phrases, highlight the main idea, summarize the main idea(s) and important detail and ask and answer questions.

Concerning CSR used by students who learn English, Klingner and Vaughn (1998) in her study suggest the four strategies in teaching reading comprehension: preview (brainstorming or prior knowledge), click and clunk (identify the difficulty and understanding material), get the gist (find out or identify the main idea(s) and information(s) and wrap up (ask and answer questions) the story from the English text books that they read (Klingner and Vaughn, 1998). 
Moreover, reading as one of those language skills being the problem faced by the most students needs to be improved. To identify the problems of reading which occurred in the reading class, the researcher conducted a pre-test. Based on the pre-test that was done by the researcher himself as an English lecturer at English department Faculty of Tarbiyah IAIN Jember, some students were able to comprehend the text well but some still had difficult time in comprehending the reading text. The data was taken from the result of students' pre-test on February $26^{\text {th }}, 2018$, and it was found that the students of TBI- 2 on the fourth semester faced some difficulties in mastering reading comprehension. There were 20 students out of 38 students who got low average score of reading comprehension (less than 60 as the minimum of passing grade) in their reading comprehension pre-test with 51.84 as the average score. It happened because they did not have any strategy to comprehend the reading text and they had limited vocabularies.

Based on those reasons, the researcher tries to offer applying Collaborative Strategic Reading (CSR) as a teaching strategy in improving the students' reading comprehension achievement at TBI-2.

Therefore, teaching reading comprehension by using Collaborative Strategic Reading (CSR) can be prepared to teach reading comprehension at TBI2 Faculty of Tarbiyah because by applying this teaching technique, the students are able to discuss and comprehend the text collaboratively.

\section{METHOD}

\section{Research Design}

The design of this study is classroom action research done in class TBI-2 Faculty of Tarbiyah IAIN Jember. It begins with the problem faced by the students in reading ability and the questions about classroom experiences, and about how to improve students' reading comprehension achievement through Collaborative Strategic Reading (CSR). It is reflective process which helps the researcher to explore and examine aspects of teaching and learning and to take action to change and improve.

Furthermore, this action research was conducted in cycles in which each cycle consists of four stages activities. They were planning the action, implementing the action, observing the classroom, evaluating and reflecting the action. Each cycle was conducted in two meetings, in which each meeting was done in 90 minutes.

\section{Setting and the Subject of the Research}

This classroom action research was carried out at TBI-2 Faculty Tarbiyah at IAIN Jember. This subject of this research is the students of the fourth semester students of TBI-2 in the 2017/2018 academic year. The number of the students learning English classroom are 38 students. The area of this research was determined purposively by considering two considerations as follow: (1) Collaborative Strategic Reading (CSR) has never been used by the students in reading class. (2) The students still have problems with reading comprehension or their reading achievement is still low. 


\section{Research Procedures}

In conducting this research, the researcher employed a series of stages; (1) planning, (2) implementing, (3) observing and ended with (4) reflecting. This one cycle is preceded by the result of preliminary study which forced and led to conduct some actions to apply a certain method.

\section{Planning the Actions}

Planning is the step in which a careful preparation is made before doing the action. This part consists of determining the teaching strategy, designing the lesson plan, and setting of criteria of success.

\section{The Teaching Strategy}

The applications of Collaborative Strategic Reading in teaching reading deal with the procedures in reading class. CSR can be implemented in two phases: (a) teaching the strategies, and (b) cooperative learning group activity or student pairing. The implementation steps described below were developed through a series of research studies (Klingner et al., 1998).

\section{Phase 1: Teaching the Strategies}

In CSR, students learn four techniques: preview, click and clunk, get the gist, and wrap up. The appropriate procedures of CSR in teaching reading are as follows:

Firstly, a teacher introduces previewing to students by brainstorming the text by looking at the pictures and the title, discussing and sharing ideas to determine the best topic, predicting the topic that will be learnt, and sharing to find the best prediction.

Secondly, the teacher describes a click and a clunk to the students and ask them identifying the difficult or unknown words, guiding the students to use context clues strategy to overcome their clunks, and sharing in group to determine the best meaning of the words

Thirdly, the teacher descibes how to get the gist to the students by identifying the text and guiding them to find the main idea of each paragraph, and sharing in group to find the best main idea of each paragraph

Finally, a teacher teaches students to wrap up by guiding the students to review the whole text by summarizing the important ideas of the text, sharing to find the best review, and answering the questions in group related to the text to check the text comprehension.

\section{Phase 2: Cooperative Learning Group or Student Pairing}

As students have learned the four strategies (preview, click and clunk, get the gist, and wrap up), they are ready to apply CSR in their cooperative learning groups. Some teachers find it easier to have students work collaboratively, and that has also proven to be a successful practice. The Procedures for implementing these strategies with groups are: First, the teacher assigns students to groups. Each group consists of 3-5 students of varying ability. Secondly, the teacher assigns roles to them. Roles should rotate on a regular basis so that students can experience a variety of roles. Possible roles include as: (1) Leader, he/she tells the group what to read next and what strategy to use next. (2) Clunk Expert, he/she 
uses clunk cards to remind the group when trying to figure out the meaning of their clunk(s). (3) Gist Expert, he/she guides the group for getting the gist and determines that the gist contains the most important idea(s) but no unnecessary details. (4) Announcer, he/she calls on group members to read a passage or share an idea.

\section{The Lesson Plan}

The lesson plans are designed with the purpose of providing the researcher as the teacher with the guidelines of teaching and learning activities. The lesson plan is developed by researcher which includes the following items: (1) the standard competence; it is the aim of the learning process in general, (2) the basic competence; it is about to explain the standard competence in a very clear way with details, (3) the indicators; it refers to the learning objectives, (4) the objectives of learning; it describes what the students will be able to do when instruction has been completed, (5) the teaching method/technique; it refers to Collaborative Strategic Reading (CSR) as a technique in teaching reading, (6) the instructional procedures; it is useful to indicate an approximate amount of time each activity within introductory, development, and closing activities, (7) the sources; it includes the sources of materials during instruction of the lesson. It is textbooks from the TOEFL books, and (8) the evaluation/assessment; it is to evaluate whether the students have achieved the objective of teaching learning process in reading by implementing Collaborative Strategic Reading (CSR).

\section{The Criteria of Success}

In classroom action research, the criteria of success used to find out how the students' improvement after implementation of the strategy. For this research, the criteria are used to see whether another cycle of the action is needed or not. In this case, the success is determined by the criterion: the average score of the students of the whole class achieve reading test is greater than or equal to 60 of the range that lies from $0-100$. The consideration of the score 60 is that has been set as the minimum passing standard.

The formula used to judge the reading score is as follows:

\section{The true item X 5}

In additions, the indicators mentioned above are also applied to decide whether the cycle proceeded to the next or needed to be quitted. The students were tested by a set of reading test. It was designed in a multiple choice test that consists of 20 items.

Furthermore, the success is also determined by the criterion: the students should achieve at least 4 indicators out of 5 indicators from observation stated in checklist. The students' active participation in teaching and learning process of reading by using Collaborative Strategic Reading (CSR) include surveying the reading text, making some questions related to the topic, reading the text, participating in group, and answering the reading exercises. It means that the requirement of $75 \%$ of the students' active participation in the teaching reading by using Collaborative Strategic Reading (CSR) should be fulfilled. 


\section{Implementing the Actions}

Implementation is a realization of some actions that have been planned in advance. The implementation of this research was planned to be done during the class hours. The actions given were teaching reading by Collaborative Strategic Reading (CSR). It was given to the research subjects in every meeting in each cycle.

The implementation of the action at the first cycle was done on March $5^{\text {th }}$, 2018 as the first meeting, and on March $12^{\text {th }}, 2018$ as the second meeting, it was continued by the reading test on March $19^{\text {th }}, 2018$ to measure the increasing of the students' ability, and check whether it was suitable with the criteria of success.

Finding that the increasing of the students' ability on reading still did not match with the criteria of success, the study was continued into the second cycle that was done on April2 ${ }^{\text {nd }}, 2018$ as the first meeting and on April9 ${ }^{\text {th }}, 2018$ as the second meeting. The reading test was done again on April $16^{\text {th }}, 2018$ to measure the increasing of students' ability in reading. Since the researcher found that the criteria of success ware fulfilled, the cycle of the action was stopped.

\section{Observing the Action}

Observation checklists are used to record the progress in each stage of learning. They are employed to record the students' activities that related the participation during the teaching and learning reading activities. In this case, the researcher filled the observation checklists from the students' responses during the teaching and learning process. Further, observation checklists is also used record the teacher's activities that reflected the implementation of strategy during the teaching reading activities.

Table 1: Observation Checklist

\begin{tabular}{|l|l|l|l|l|l|l|l|}
\hline NO & \multirow{2}{*}{ Students' Name In } & \multicolumn{3}{|l|}{ Meeting 1 } & \multirow{2}{l|}{ Active } \\
\cline { 3 - 7 } & & $1^{*}$ & $2^{*}$ & $3^{*}$ & $4^{*}$ & $5^{*}$ & \\
\hline 1 & & & & & & & \\
\hline 2 & & & & & & & \\
\hline 3 & & & & & & & \\
\hline
\end{tabular}

Notes:

$1 *$ : Surveying the reading text related to the topic

$2 *$ : Making some questions related to the topic

$3^{*}$ : Reading the text carefully

$4^{*}$ : Participating in group

$5^{*}$ : Answering the reading exercises

The above table indicates the students' active participation in teaching and learning process of reading by using Collaborative Strategic Reading (CSR). They should achieve at least 4 indicators of observation stated in the checklist. The students' active participation in teaching and learning process of reading by using 
Collaborative Strategic Reading (CSR) include surveying the reading text, making some questions related to the topic, reading the text, participating in group, and answering the reading exercises.

\section{Reflecting and the Data Analysis}

Reflecting became a vital activity to analyze, to synthesize, to interpret and to explain the collected information gathered from different sources of data. The other significance of this section is to compare the result of conducted assessment and the criteria of success predetermined. The conclusion of the reflection is obviously used as fundamental information to hold the following action. If the results in a cycle had achieved the criteria of success, the study was said successful and otherwise if the results did not meet the predetermined criteria of success, it would be necessary to prepare the following cycle by making important revision on the parts of planning, implementing and observing.

The results of the reading comprehension achievement in the form of scores were analyzed quantitatively. The results of the data analysis were classified qualitatively based on the classification of the score levels. The quantitative formulation for analyzing the students' reading achievement in the form of scores is as follows:

\section{$\mathbf{E}=\mathbf{n} / \mathbf{N} \times 100 \%$}

Note:

E: The percentage of the research subjects who reached the targeted score $\geq 60$

$\mathrm{n}$ : The total number of the research subjects who reached the targeted score $\geq 60$

$\mathrm{N}$ : The total number of the research subjects who took the test.

(Adopted from Ali, 1993:186)

\section{FINDINGS}

\section{Research Findings of the Actions in Cycle 1}

The reading materials taught in the first meeting and in the second meeting were taken from Longman Introductory Course for the TOEFL Test by implementing Collaborative Strategic Reading (CSR) in teaching reading. At the end of the first cycle, the reading comprehension test was administered in the third meeting (on March $19^{\text {th }}, 2018$ ). In the reading test, there were five texts. They were taken from Longman Introductory Course for the TOEFL test.

\section{The Result of Observation in Cycle 1}

The class observation in the second meeting showed that 22 students or $57.89 \%$ of the students were active in the teaching learning process of reading by using Collaborative Strategic Reading (CSR). This means that the observation results in the first cycle has not been fulfilled yet because they had not achieved the standard requirement in this research. As a result, the actions were continued to the second cycle. 


\section{The Results of the Students' Reading Comprehension Test in Cycle 1}

The percentage of the students' reading comprehension achievement test score in the first cycle was $50.00 \%$ of 38 students who got score $\geq 60$. The action of this research was considered to be successful if $75 \%$ of the total number of the students achieved the targeted score that was $\geq 60$. In fact, there were $50.00 \%$ (19 students) of the students who reached reading comprehension achievement score $\geq 60$. This means that the targeted percentage of the students gaining the core $\geq 60$ had not been achieved. From the fact above, it can be concluded that action in the first cycle was not successful yet. Therefore, it was necessary to proceed the action to the following cycle.

\section{The Results of the Reflection in Cycle 1}

The reflection was done based on the result of reading comprehension test score and the observation. Based on the results of observation, it was found that 22 students or $57.89 \%$ of the students were active in the second meeting during the teaching learning process of reading. It means that the requirements of $75 \%$ of the students active participation in the teaching learning process of reading comprehension by using Collaborative Strategic Reading (CSR) was not fulfilled. Meanwhile, based on the product evaluation, the result of reading comprehension test score in the first cycle showed that the percentage of the students who go reading comprehension score $\geq 60$ was $50.00 \%$. Meanwhile, it was targeted that $75 \%$ of the total students could achieve the targeted score of reading comprehension at least $\geq 60$. However, there were $50.00 \%$ (19 students) of the total students who could achieve the targeted score required. Therefore, the actions of Cycle 2 were needed to improve the students' reading comprehension achievement.

Based on the result of the observation and the students' reading comprehension test in cycle 1 , the researcher revised some aspects in cycle 2 . Firstly, the teacher gave more explanation and procedures in implementing Collaborative Strategic Reading (CSR) not only in English but also in Indonesian, so that the students could apply this technique well. Secondly, the teacher instructed the students to work collaboratively in order they have equal participation in discussing and comprehending the texts. Furthermore, the teacher reminded them that they are a team to achieve the goal as their roles in group. Thirdly, the teacher assigned different roles to them in cycle 2, so that students could experience a variety of roles. The leader in cycle 1 became the clunk expert in cycle 2 and vice versa, and the gist expert in cycle 1 became the announcer in cycle 2 and vice versa.

\section{Research Findings of the Actions in Cycle 2}

The actions in Cycle 2 were done because the actions in Cycle 1 had not reached the research objectives yet. The implementation of the action was based on the revised lesson plan made by the researcher. The researcher expected that after the actions in Cycle 2, the results of the students' reading test would be better than those of the Cycle 1 and as it was expected it could improve the students' reading comprehension achievement through Collaborative Strategic Reading (CSR). The reading materials taught in the first meeting and in the 
second meeting were taken from Longman Complete Course for the TOEFL Test by implementing Collaborative Strategic Reading (CSR) in teaching reading.

At the end of the second cycle, the reading comprehension test was also administered to measure the students' reading comprehension achievement. It was done in the third meeting, on April $16^{\text {th }}, 2018$. The material used in the reading comprehension test was TOEFL posttest that was taken from Longman Complete Course for the TOEFL Test.

\section{The Results of Observation in Cycle 2}

In Cycle 2, the students were asked to do the activities in groups. Based on the result of observation in the second meeting in Cycle 2, it was found that most of the students (36 students or $94.74 \%$ of 38 students) were actively involved in the teaching learning process of reading by using Collaborative Strategic Reading (CSR). It means that the requirement of $75 \%$ of the students' active participation in the teaching reading by using Collaborative Strategic Reading (CSR) had been fulfilled.

\section{The Results of the Students' Reading Comprehension Test in Cycle 2}

The percentage of the students' reading comprehension achievement in Cycle 2 was higher than the percentage of Cycle 1 (from $50.00 \%$ to $89.47 \%$ ). In this cycle, there were $89.47 \%$ or 34 students having reading comprehension score $\geq 60$. But, there were 4 students or $10.53 \%$ of 38 students who got below of the standard score in the second cycle. From those results, it can be said that in Cycle 2 , the percentage of the students who reached the targeted score of 60 or higher could be achieved. It can be concluded that the action of teaching reading comprehension in Cycle 2 had achieved the target criteria and it can improve the students' reading comprehension achievement. Consequently, the action was stopped.

\section{The Results of the Reflection in Cycle 2}

The improvement of the percentage of the students who got the score of reading comprehension test $\geq 60$ happened. It was indicated by the result of the reading test score of Cycle 2, there were 34 students or $89.47 \%$ of the students had score $\geq 60$. It was higher than the results in Cycle $1(50.00 \%)$. It means that the percentage targeted that was $75 \%$ of the students got the score at least 60 or higher in this research had been achieved. It was also followed by the improvement of the observation result. In Cycle 1, there were only 22 students or $57.89 \%$ out of 38 students who actively participated in the teaching learning process of reading. While, in Cycle 2, there were 36 students or $94.74 \%$ out of 38 students who actively participated in the lesson. Those results showed that the result of observation also fulfilled the percentage targeted in this research that was $75 \%$ of the students actively participated in the teaching learning process. It means that this research had successfully achieved the research target criteria. Therefore, the actions of this research were stopped because the research was considered successful. 


\section{DISCUSSIONS}

\section{Improvement of the Students' Ability from Cycle 1 to Cycle 2}

Based on the results of the implementation of the actions in cycles, in general the students' reading comprehension achievement and participation can be described as follows:

In the first cycle, the students' reading comprehension achievement had not achieved the criteria successes of this research. Besides, from the observation results, the students still experienced difficulties in the teaching learning process of reading in the first time. The students' difficulties appeared in participating in group. Some students dominated the group and some students did not have opportunities equally, so the students who got low ability could not comprehend the texts well. It could be seen from the results of the observation in Cycle 1. In the first cycle, there were only $57.89 \%$ or 22 students out of 38 students who actively participated in the teaching learning process of reading because they had fulfilled at least four out of five indicators being observed. While, $42.11 \%$ or 16 students out of 38 students were not active to participate in the teaching learning process because they only fulfilled less than five of the indicators being observed. Concerning the reasons, the researcher revises some necessary aspects that caused the failure in Cycle 1 and applied them in the second cycle.

In the second cycle, the students were given more explanation and procedures in Collaborative Strategic Reading (CSR) not only in English but also in Indonesian, so that the students could apply this technique well. Furthermore, the teacher instructed the students to work collaboratively in order they have equal participation in discussing and comprehending the texts. Moreover, the teacher reminded them that they are a team to achieve the goal as their roles in group. By doing so, the students could get the idea clearer and could comprehend the text well. There were $94.74 \%$ or 36 students out of 38 students who actively participated in the teaching learning process of reading.

After conducting the actions in the Cycle 2 by revising some necessary aspects, the percentage of the students who reached the standard score requirement of reading comprehension test at least 60 or more increased from $50.00 \%$ with 57.89 as the average score (Cycle 1) to $89.47 \%$ with 71.18 as the average score (Cycle 2).

The teacher had to believe that Collaborative Strategic Reading gave benefits to the students in reading comprehension achievement. The finding was in line with Klingner, Alison, \& Sharon in Young, Michael, \& Citro (2018) who stated that Collaborative Strategic Reading was designed to capitalize the effective practices to enhance the understanding of and learning from text. In other words, the students are able to comprehend the text easier by learning collaboratively.

The result of observation and reading comprehension achievement test in Cycle 1 and Cycle 2 indicated that Collaborative Strategic Reading (CSR) could be applied as one of the effective strategy in teaching reading comprehension. As a conclusion, Collaborative Strategic Reading (CSR) could improve the ability of the forth semester students of TBI-2 Faculty of Tarbiyah at IAIN Jember in reading comprehension achievement. 


\section{CONCLUSIONS AND SUGGESTIONS Conclusions}

The research results and the discussions show that using Collaborative Strategic Reading (CSR) improved the students' reading comprehension achievement. This was proved by the fact that the percentage of the students who got the score of at least 60 increased from $50.00 \%$ in Cycle 1 with 57.89 as the average score to $89.47 \%$ in Cycle 2 with 71.18 as the average score. Besides, the use of Collaborative Strategic Reading (CSR) also improved the students' active participation in the teaching learning process of reading. This can be seen from the fact that the percentage of the students who are actively participated in classroom activities increased from $57.89 \%$ in Cycle 1 to $94.74 \%$ in Cycle 2 . The results show that the use of Collaborative Strategic Reading (CSR) managed to improve the students' reading comprehension achievement and the students' active participation during the teaching and learning process.

\section{Suggestions}

By considering the results that the use of Collaborative Strategic Reading (CSR) can improve the students' reading comprehension achievement and the students' active participation in the teaching learning process of reading, some suggestions were proposed to the English teacher and the future researchers. It is suggested that English teacher use Collaborative Strategic Reading (CSR) as alternative strategy in teaching reading to improve the students' reading comprehension achievement and the students' active participation. Thus, the future researchers of the English teacher who are more likely to experience the similar problems are suggested to conduct further classroom action research dealing with those problems to improve the quality of the students' reading comprehension achievement and the students' active participation during the teaching learning process of reading.

\section{REFERENCES}

Ali, H. M. (1993). Strategi Penelitian Pendidikan. Bandung: Angkasa.

Best, R.M., Rowe, M., Ozuru, Y., \& McNamara, D.S. (2005) Deep-Level Comprehension of Science Texts. Topic in Language Disorders, 25(1), 65-83

Boss, C. S and Vaughn, s. (1991). Strategies for Teaching Students with Learning and Behavior Problem. Massachusetts: Allyn and Bacon.

Carrell, P. L, Joanne, D. and David E. Eskey. (1988). Interactive Approaches to Second Language Reading. Cambridge: Cambridge University Press.

Fairbairn, G. J. and C. Wich. (1996). Reading, Writing and Reasoning: a Guide for Students (Second Edition). Philadelphia: Open University Press.

Grellet, F. (1981). Developing Reading Skills. Cambridge: Cambridge University Press.

Hennings, D.C. (1997). Communication in Action: Teaching Literature-Based Language Arts (Sixth Edition). Boston: Houghton Mifflin Company. 
Klingner, J. K. \& Vaughn, S. (1996). Reciprocal Tteaching of Reading Comprehension Strategies for Students with Learning Disabilities who Use English as a Second Language. The Elementary School Journal, 96(3), 275-293.

Klingner, J. K. \& Vaughn, S. (1998). Using Collaborative Strategic Reading. Teaching Exceptional Children, 30(6), 3237.Available: http://www.ldonline.org/ld_indepth/teaching_techniques/col lab_reading.html

Klingner, J. K. \& Vaughn, S. (1999). Promoting ReadingComprehension, ContentLearning, and English Acquisition through Collaborative Strategic Reading (CSR). The Reading Teacher, 52(7), 738-747.

Klingner, J. K., \& Vaughn, S. (2000). The Helping Behaviors of Fifth Graders while Using Collaborative Strategic Reading during ESL Content Classes. TESOL Quarterly, 34(1), 69-98.

Klingner, J. K., Vaughn, S., Dimino, J., Schumm, J. S., \& Bryant, D. (2001). From Clunk to Click: Collaborative Strategic Reading. Longmont, CO: Sopris West.

Klingner, J. K., Vaughn, S., Hughes, M. T., Schumm, J. S., \&Elbaum, B. (1998). Outcomes for Students with and without Learning Disabilities in Inclusive Classrooms, Learning Disabilities Research \& Practice, 13(3), 153-161.

Sneddon, J. (2003). The Indonesian Language, Its History and Role in Modern Society. Sydney: NSW Press.

Vaughn, S., Chard, D., Bryant, D. P., Coleman, M., Tyler, B., Thompson, S., \&Kouzekanani, K. (2000). Fluency and Comprehension Interventions for Third-Grade Students: Two Paths to Improve Fluency. Remedial and Special Education, 21(6), 325-335.

Vaughn, S., Klingner, J. K., \& Bryant, D. P. (2001). Collaborative StrategicReading as a Means to EnhancePeer-mediated Instruction for ReadingComprehension and ContentArea Learning. Remedial and Special Education, 22(2), 66-74.

Wood, N. V. (1991). Strategies for College Reading and Thinking. New York: McGraw-Hill, Inc.

Wood, N.V. (1996). College Reading and Study Skills: Learning, Thinking, Making Connection (Fifth Edition). Orlando: Harcourt Brace College Publishers.

Young, N. D., Michael, C. N., \& Citro, T.A. (2018). From Floundering to Fluent. Reaching and Teaching Struggling Readers. London: The Rowman \& Littlefield Publishing Group, Inc. 